\title{
Stanisław Brzozowski on the ideal of the modern man
}

\author{
Anna Dziedzic
}

Published online: 20 October 2011

(C) The Author(s) 2011. This article is published with open access at Springerlink.com

\begin{abstract}
Stanisław Brzozowski formulated the ideal of modern man in the polemic with the contemporary man, who has ceased to believe in truth and moral values and is devoid of the will to act. For Brzozowski modernity involves the discovery of truth about the human condition: about man as an autonomous subject, a creator of values, who struggles with non-human reality. This truth was formulated in Kant's idea of autonomy and in Marx' idea of a collective conquest of the world of nature. For Brzozowski, ideal modern man is "the conscious labourer," who labours because he wants to proudly impose a human law on the non-human world. At the same time Brzozowski used the term "modernity" to describe life of constant change in the modern world, understood as a set of results of man's reign over nature. For the sake of human maturity, Brzozowski expected the truly modern man to perceive modern life as an unquestionable value. Undoubtedly, there is an evident tension in Brzozowski's ideal of modern man between the affirmation of creativity in the world of change and the necessity of disciplined production, including unchangeable moral foundations of labour. There is also a major shift in this ideal, stemming from Brzozowski's change of attitude towards religion.
\end{abstract}

Keywords Stanisław Brzozowski · Modernity · A modern man · A contemporary man · Autonomy $\cdot$ Creativity $\cdot$ A conscious labourer $\cdot$ The philosophy of labour

Stanisław Brzozowski used the term "modern man" in two contexts: one critical and the other positive. This is why, in his texts, we can read both that modern man is devoid of the will to act, is searching for his "self" in the area of thought divorced from life (Brzozowski 1910a, 386), and that modern man is disgusted with the

\footnotetext{
A. Dziedzic $(\bowtie)$

Institute of Philosophy and Sociology, The University of Warsaw, Warsaw, Poland e-mail: dziedzicanna4@wp.pl
} 
psychological type who cannot act (Brzozowski 1909a/2007, 181). For Brzozowski, the truly modern man is someone who can act; such a person understands modernity and can undertake its challenge. The first type, on the other hand, is the contemporary man, criticised by Brzozowski. The ideal of a modern man is formulated here in the polemic with the contemporary man, who only perceives himselves to be modern. The philosophy of Brzozowski is a philosophical consolation, offered to contemporary man, to assist him to go from powerlessness to being truly modern.

The experience of modernity that Brzozowski tackled in the first period of his intellectual activity is the experience of the fall of all absolute norms and values. For Brzozowski, the self-knowledge of modernity was brought to expression by Richard Avenarius, Friedrich Nietzsche, and Stanisław Przybyszewski. Avenarius' empiriocriticism was the highest stage of the naturalistic, positivist theory of cognition according to which human cognition is the process of the organism's adaptation to its environment; questions about absolute truth are meaningless. Nietzsche perceived the world "beyond good and evil" as well as the kind of man whose "historical sense" will help him understand all historical, variable, and distant cultural standpoints and values; though this man himself does not know who he is. Przybyszewski articulated in his novels and plays man's despair and helplessness, described in naturalistic, evolutionistic and deterministic categoriesman who is not at the core of his action, but is a part of the natural course of causes and effects, the space of interacting non-human forces. Przybyszewski, the author of the phrase: "we, who were born late, have ceased to believe in truth," became for the young Brzozowski the voice of contemporary man, who, under the influence of naturalism and historicism has lost his self-confidence, who withholds any credence from human values. Contrary to Przybyszewski, however, Brzozowski refused to languish in despair, affirming instead that each human individual has significance for culture and in such texts as Filozofia czynu (The Philosophy of Action) encouraging man to think of himself as creative. Later, in 1904, inspired by Kant's philosophy, Brzozowski found a philosophical justification for faith in human autonomy, creativity, and freedom. Ideas about man as solely a fact in the world of facts, subject to the forces of nature and the historical process, are now unmasked as wrong as they confuse the order of facts with order of values. Human creativity and freedom cannot be negated, the autonomy of man is primary, and there are no nonhuman truths and values obliging us to obedience. According to Brzozowski, naturalistic theories of progress (including evolutionistically interpreted Marxism) make the same error as the priests and symbolist poets who try to decipher the hidden order of existence: they fail to see that a "ready-made world" of non-human truths and values does not exists, there is only our free creation and its cultural results.

When Brzozowski, following Kant, demonstrated that freedom and creativity are real, the absence of absolute norms has turned into discovery of the autonomy of man-the creator. Kant turned out to be the first modern philosopher, where the heart of modernity is - in contrast to the Middle Ages - the discovery of the self-contained nature of man. The sense of disintegration of the human subject, previously so bemoaned by Brzozowski, turned out to be a misunderstanding stemming from the inability to understand modernity. 
At the next stage of his intellectual path, when formulating the "philosophy of labour," Brzozowski discovered Marx as the author of the thesis that the prevailing values belong to those who have real force to organise and re-shape the social and material world; that cultural significance belongs to those social classes which are able to increase humanity's capacity for production (Brzozowski 1906a/1973). Following his philosophical discovery of human autonomy, Brzozowski asked how man imposes his own law on non-human reality. The answer was: through conquest of the unfriendly world of nature by means of scientific and technological progress. The measure of human freedom turned out to be independence from chance to rule over the non-human element. A modern man understands that only through his labour is he able to introduce changes in the world of nature and increase his own freedom. What the modern man wants is that there nothing be left to itself, beyond his control: " Man must take control of his life in such a way that there be nothing in him, in his own soul, except what he has consciously intended and created" (Brzozowski 1910a, 16).

The ideal of the modern man turns out to be the "conscious labourer," who continues scientific and technological progress on the same or higher level as the worker in the capitalist system, but with a different self-awareness and labour organisation. In the society of conscious labourers, labour is not subject to values disconnected from work and opposed to work, but on the contrary culture will arise based on reverence and pride for the Promethean oeuvre of labour. The conscious labourer does not work because he has to, nor does he believe that consumption is the objective and justification of the effort. He works because he wants to, proud of being a man-an autonomous subject, a creator.

From the point of view of the philosophy of labour articulated in 1906-1907, modernity involves the discovery of truth about the human condition, man's achievement of maturity. It is the time to understand that "humanity is driving stilts into the bottom (...) of non-human chaos (..). It erects its own life on its own ground. (...) Man has only himself and disposes only of himself and what he purposefully creates" (Brzozowski 1907a/1990, 203). Modern man is someone who is able to face the human condition, who understands that the world is not readymade, but constitutes a space for his creativity and effort; who is a creator of meaning in a world without God.

At the same time, the term "modernity" is used by Brzozowski in a different sense: to describe life in the modern world, understood as the set of results of man's increasing reign over nature and the development of technology. Modern life is the world of constant change, where "every day and hour almost all forms developed yesterday" are destroyed, where "more and more new connections between people, more and more new issues and tasks" are created, while "what existed yesterday as a binding form today belongs to the past, and tomorrow today's norm will undergo the same fate. Nothing is ultimately binding. Man grows accustomed to the volatility of the forms of social life, of relations and moral, or at least conventional, notions that stem from it. He becomes used to their volatility, and also to putting increasingly the new social order, the new relations and new cultural atmosphere to use" (Brzozowski 1907b/1973, 649). The modern world is a reality of intensified human production, thus the enormous intensity of changes and new challenges, and 
the lack of defined objectives of human action, given once and for all. Modern man seems to be flexible enough to adjust to this dynamic environment, he does not grumble about the fall of the absolute, but takes advantage of the new arrangements of cultural elements to further his creativity. At the same time, the growth in the dynamics of life brought about by capitalism and industrialism makes a terrifying impression: "The wheels thunder, transmissions struggle, the terrible machine is turning, and the more powerful the rampancy of the impetuous human will the less significant it becomes in the face of its own creation; and our entire Western civilisation seems to be some terrible disaster carrying us along with it. It is so powerful and overpowering that we cannot resist it; we must run forward with it" (...); "From the side of its material foundations, modern culture is a complex entanglement of machines (...). It is a Gothic architecture of machines, an apocalyptic combat of steel and iron monsters endlessly destroying each other (...)" (Brzozowski 1910a, 296-297). Brzozowski does emphasise, however, that behind all that is mechanical stands human will and effort. It is not the machine that overwhelms the man, but the choices and efforts of some people clash with the choices and efforts of others; what for some is an experienced as a constraint is the product of the freedom of others. At the same time, the unpredictability of existing results of human creation does not free us from responsibility for them.

Thus, for Brzozowski, modernity has two dimensions: it is a time of recognition of truth about man as an autonomous creator and the world of speed, change, machines, sweat, and effort. Admitting the truth about the human condition and consenting to participate in modern life are two overlapping acts. Being a modern man in ceaseless effort, working in an open world that is not ready-made, is also described by Brzozowski as being "masculine"-contrary to being childish. Turning one's back on the modern world is childish, as we cannot make human life be something other than it is: labour, struggle with the chaos of nature, creativity. The world of modern creativity is man's normal environment; escaping from modernity is escaping from life and from oneself, the pride in being a man is the pride in being a modern man. The modern man must thus stay himself, he must boldly and proudly continue his Promethean conquest of nature, he must demonstrate force and bravery, increase the power of his creative will. He must, however, enter the higher, socialist level of modernity: take collective responsibility for the products of his work, which now have gotten out of control.

Meanwhile, contemporary man, criticised by Brzozowski, relinquishes his responsibility, escapes from reality, and treats the necessity of effort as an injustice. The man who cheats himself, the pseudo-modern man from the point of view of the "philosophy of labour," is anybody who believes that there are other forms or ways of life, higher than labour or whatever serves labour's purposes; it is also anyone who doesn't work and therefore forgets man's true identity. In this respect, there was only an apparent distance between such standpoints and attitudes as: positivism, naturalism, fin-de-siècle decadence and aestheticism, idealistic rebellion against the modern world, the spectator's attitude to the history of culture, faith in automatic progress, and faith in the possibility of a socialist society with less labour. Likewise revealed as pseudo-modern were empiriocriticism, the despairing Przybyszewski, and Nietzsche, who did not understand the value of collective effort in the conquest 
of nature preferring pseudo-individualism, which is possible as a life standpoint only because it takes advantage of the labour of others.

Gradually, Brzozowski deepened his idea of labour as creation under specific social and individual conditions. Brzozowski finally relinquished Marx; in 1909-1910 Sorel, Proudhon, and Bergson inspire Brzozowski to develop and defend the philosophy of labour. Marx, though set off from Engels' naturalism and evolutionism, nevertheless did not understand the psychology of the producer. In a campaign against rationalism and sentimentalism, which took the form of criticism directed to the intelligentsia as a social stratum completely disconnected from life and taking advantage of the labour of others - and is thus a stratum devoid of the moral right to impose goals and value systems on workers-Brzozowski highlighted the real requirements which a man must meet in order to work. The ideal of the modern man that emerges from Brzozowski's writings is an expression of the need for a proud, victorious control over nature and mastery of the dynamics of modern processes, but also for humility, devoid of illusions, concerning the tough requirements of life as struggle. Brzozowski looks at the people to whom the future belongs - the working men, asking what are his beliefs, values, customs, and religious ideas. He indicates the indispensable biological and social conditions necessary for humanity to reproduce and increase its Promethean power, the necessity to bring new generations to life, raised in the spirit of the philosophy of labour. Labour requires discipline of will and social systems that produce and sustain it. What is needed first of all in order to master the external elements is mastery of the internal elements, nature within, in order to build a disciplined personality with a strong will; what is needed and morally valuable is the institution of the family and strict sexual morality.

The conscious labourer, or the ideal modern man, knows that his life "should in every way be like the knight's search for adventure, or like the expeditions of halfcrazed sailors across uncharted seas" (Brzozowski 1910b/2007, 125); he shares the dream of growth of human will and conscious reign over the world. He understands that nothing is really won, he accepts human life as a struggle, "continuous effort and labour" (Brzozowski 1910c/1990, 404), and perceives it as a value. The ideal modern man can live in an "unfinished" world of movement and change without losing his individual character. He does not treat his presence as something temporary, transient; he wants to create, materialise his values, thus he lives as if he were "eternal, everlasting," believing in the rightness of his truth and the significance of his actions (Brzozowski 1907c/2007, 166). The stability of modern man's personality does not stem from the existence of a given, stable "self"; it is a personality created in time, the result of discipline and devotion to tasks faced by humanity. The modern man desires to contribute something new, uniqueindividual - to the world. He is a strong personality who believes in himself and in the value of his specific, everyday life (this notion was strongly emphasised by Brzozowski as a result of his reading of John H. Newman and the English Romantics). However, the true individuality is not realised within her private space, does not involve escape into randomness and democratic lawlessness. The individual is real only to the extent that it is and feels the part of the organised will, the organised world (Brzozowski 1910d/1990, 425). Modern man understands 
that increasing human power and creative force requires discipline of the will and social discipline, its needs socially proven customs and habits. He understands that love is not an issue for his private sentiments, but is a matter of creating the biological foundations of labouring humanity. He proudly bears the necessity of his everyday burden knowing that his life has a supra-individual sense (Brzozowski $1910 \mathrm{e} / 1990,361)$, that culture requires subjugating the "self" and does not take into account the frailty of our personal forces. And being part of an organised will means, in Brzozowski's later philosophy, subjugation to the nation, as the nation is the only form of "humanity" with which we deal directly. The modern man thus takes part in the rivalry of nations; not only does he agree to the rivalry and the struggle between nations, but he holds it to be valuable, this kind of approval being called by Brzozowski "modern realism” (Brzozowski 1909b/2007, 232).

What draws attention is the fact that in his analysis of modernity Brzozowski treats modern life as the fullest expression of life as such. For Brzozowski "progress, change, eternal movement - these are the essence of life; whatever does not participate in movement, whatever shuts itself up, is doomed to death and extinction" (Brzozowski 1907d/1973, 496), and the unfinished state of the world along with the dynamics of life go hand in hand with the need for initiative, "the will to things new and unpredictable" (Brzozowski 1910a, 150). In fact, when thinking about modernity, Brzozowski develops a kind of Lebensphilosophie, a matter of considerable significance. It is worth recalling that in classical concepts of Lebensphilosophie - from Guyau to Nietzsche, Bergson, and in some sense Jamesthe cult of life, as the greatest richness and expansiveness of life-are values per se. The very fact of living created the moral obligation to reinforce life; values evinced a practical character and were judged according to whether they serve' life's dynamic. Though Brzozowski stands far apart from the naturalistic tenor of these notions, his thinking is structurally similar to Lebensphilosophie, bridging the gap between the order of the facts and the order of the values. This is visible in such statements as: "our forever striving, feverish essence, this is reality, our modern reality, which needs no justification beyond itself" (Brzozowski 1910c/1990, 404). Modernity requires no justification, its value is intrinsic. Having equated modern life with life as such, we have no possibility to question the value of modern life, and compassion for other nations must be perceived as jesuitical (Brzozowski 1909a/2007, 177). Asking about the value of seeking unlimited reign over nature or, on the other hand, asking about the value of cosmopolitanism is senseless - such questions only reveal weakness and fear of life.

The Kantian separation of the orders of facts and values was of extreme significance for Brzozowski in his struggle against the positivist paradigm which negated human autonomy. Ultimately, however, Brzozowski moves within two distinct anti-positivist perspectives: one is Kantian, consisting of an anti-naturalist understanding of man as creator, establishing values and acting in light of them, and the other is inspired by Nietzsche's, and later Bergson's, Lebensphilosophie-a philosophy which has a debt to naturalism. Common to both perspectives is the emphasis put on human spontaneity. Thus, modern man perceives his life as valuable, in line with his image as a creator, yet at the same time the only criterion of value is the increase and reinforcement of life; increasing life turns out to be both 
modern and good. Brzozowski combined these two perspectives when formulating the "philosophy of labour," in the course of his transition from Kant to Marx. Brzozowski could write at that moment: "Marxism teaches us to seek the guidelines for new social ideals in the very development of society (...). Each ideal is a moral value only when it satisfies the Kantian test of moral autonomy, when it results from and is an outcome of the development of life" (Brzozowski 1906b/1973, 371). The peculiar combination of the Kantian idea of moral autonomy with the category of "life" was possible thanks only to the previous link of the notion of "autonomy" with the life of collective man, who increases the potential of his forces of production, as described by Marx. Moral value turns out ultimately to be whatever serves man's life-within a specific society and historical moment—and increases the degree of his real freedom, that is, his reign over nature and the increase in his nation's biological and cultural potential.

We must also pay attention to the fact that when diagnosing the modern world and man's condition as a creator, Brzozowski speaks at the same time of two various spheres: unlimited creativity and disciplined production. Having found a real, material dimension of human autonomy, Brzozowski links creativity and freedom with labour. But creativity and production do not always overlap and are even antagonistic. Is modern man someone who first of all gets used to the movement, who lives with the desire to create, change, and constantly modifies the material, social, and individual world? Or does he seek foresight, mastery, purposeful management, mastery of modernity, acquiring control? The antagonism of the interests of creativity and production can be seen explicitly in the context of Brzozowski's aesthetics, for example in his book Wspótczesna krytyka literacka $w$ Polsce (Modern literary criticism in Poland), where the encouragement to affirm and sustain unpredictable creativity clashes with the emphasis on the ancillary nature of literature in regard to labour. Brzozowski indicates that what seems to be permanent and unchangeable in a given moment is a result of labour, that the world is unfinished and that there is always open space for new things. This is why literary criticism cannot stifle any manifestation of creativity, cannot speak on behalf of any particular future or aesthetic, as this would be the dogmatic suppression of creativity. At the same time, it turns out that there is a test, a measure of the value of a literary work, viz., the degree to which it takes up and reflects the problems of labouring humanity. It is literature with a positive impact on labour, on the general feeling of workers or about raising awareness of "the true and positive needs of humanity" (Brzozowski 1907e, 74). Creativity, broadly understood, is thus finally subjugated to Promethean, collective production. This is why certain kinds of art, for example those defined as "sentimental," are derided by Brzozowski, while others are praised, such as sculptures by Dunikowski, which well reflect the pathos of human effort (Brzozowski 1910c/1990, 405).

This tension between the affirmation of creativity and the specific image of modern society, in which production processes have been mastered, is structurally similar to the paradox in which Marx, as a philosopher of modernity, was entangled. ${ }^{1}$ Marx praised the bourgeoisie for creativity, romanticism, bold activity,

\footnotetext{
$\overline{1}$ Such an interpretation has been proposed by Berman (1983).
} 
which found its expression in industrialisation and the conquest of nature; at the same time, however, the bourgeoisie was an object of criticism, as it failed to follow consistently the path of creativity. It subjugated human activity to the demands of the market, stifling other human skills and requiring acceptance of the current social structure. Meanwhile bourgeois modernity - the world of permanent change, where "all that is solid melts into air" (The Communist Manifesto)_produces a man who denies the limits of capitalist society, its waste of creative forces, its belief in its own stability. The Marxist diagnosis of modernity teaches that modern, creative men must not only be open to change but learn to demand change, "actively seeking them out and carrying them through," "to find delight in mobility, thrive on renewal, to look forward to future developments in their conditions of life and their relations with their fellow men" (Berman 1983, 95-96). Meanwhile, Marx sees the deepening of modernity in the establishment of a communist society, collectively reigning over the forces of production - a society, which will be a kind of a happy finale of modernity, where such values as workers' solidarity will prove permanent and solid. Those who are truly modern will no longer expect modifications in their mutual relations, as they will acquire their optimal, communist shape; nor will there be full affirmation of various and changeable goals. However, in view of what Marx said previously, there is no criterion to ascertain that some human values and social organisations will be constant, and that in the name of modernity no further reconfiguration of those will occur; that certain human aspirations will be of a casual character and others permanent (Berman 1983, 110). Thus, Marx's reflections are marked by an inherent tension: modernity's problems may be resolved through a deeper modernity, namely communism, but this proposal—contrary to its author's intentionsfinds no justification in his analysis of modernity.

Although, Brzozowski finally abandons Marx to search for inspiration elsewhere, tension remains. Though modern man lives in a dynamic world and is supposed to will the new and the unexpected, certain areas of human life are beyond innovation, and creative individuality cannot create and seek new experiences should they impede the growth of the humanity's forces of production. Brzozowski does not promise the Marxian communist utopia, where all major human conflicts will miraculously disappear. Nevertheless, for Brzozowski, too, modernity has to be mastered. Although yesterday's binding forms today belong to the past, in the world of deeper modernity the moral, traditional foundations of labour will be inviolable, and there will be no place in art for sentimentalism. Modernity, for Brzozowski, is so inseparably linked with the notion of labour, with the rule of man over nature, over the results of labour and over himself, that whatever does not enhance the power of man and does not emphasise the heroism of labour is considered uncreative and non-modern; some form of moral, social, national conservatism can, on the other hand, turn out to be modern.

We must also pay attention to the change in the ideal of the modern man, related to the development of the philosophy of labour. The greatest difference is Brzozowski's change of attitude towards religion. When formulating his philosophy of labour, Brzozowski linked autonomy with the creation of meaning in a world without God. That is why he wrote in 1907 that modern man does not even struggle against the Church since in the face of modernity it is an entirely obsolete institution 
(Brzozowski 1907d/1973, 498), and that religion teaches us to relinquish responsibility for the world, not to consciously create the world (Brzozowski 1907f/1973, 536-537). However, in 1909-1910 he saw in the Catholic Church a historically permanent institution that shapes the collective will; he realised that religion assists in harnessing subconscious, irrational creative forces and cements the sense of community. Above all, he became interested in the thought of Cardinal Newman and Catholic modernism. Finally, for Brzozowski, modern man turned out to be a Catholic (as Protestantism seemed too individualistic). It was the kind of Catholicism the road to which led through the philosophy of labour and the Catholicism comprised in the philosophy of labour.

How can an anthropocentric philosophy of labour be reconciled with religious belief in the non-human meaning of the world? Andrzej Walicki found that Brzozowski did not succeed in overcoming this difficulty on philosophical grounds. (Walicki 1977, 393) It needs to be noted, however, that the inspiration from Catholic modernism - not only from Newman and the thought of Loisy, but perhaps first of all from Blondel's philosophy of action, whose significance Brzozowski underscored in his Diary and Letters-did not require the mere erasure of anthropocentrism for the sake of theism. Brzozowski did not renounce the pathos of the philosophy of labour; theism was, so to speak, erected on top of anthropocentrism. The ceaseless effort of human labour was being sanctified, and as with Kant the divine reality must confirm the order of values autonomously defined by man.

In the work of Brzozowski, we see the apology of Western man and a recipe for healing contemporary man who is supposed to be liberated by an act of existential and cultural self-knowledge. In fact, Brzozowski does propose his own utopia, a possibility for reconciliation of antagonisms hitherto never reconciled: those opposing the freedom of innovation to rootedness in established customs and habits, or else the value of individualism opposed to the requirements of community, or relinquishing naive consolation from religion contrasted with acquiring strength from some form of Catholicism. Contrary to Irzykowski, Brzozowski believed that modern man is not one who hesitates as he perceives more and more value conflicts, but instead finds a new source of power and self-confidence. The perfect modernity of Brzozowski seems to be disciplined, devoid of the liberal concept of freedom, marked with the undisputable need for power, and unequivocal explicitness. And the ideal modern man copes easily with all the tensions of modernity.

Open Access This article is distributed under the terms of the Creative Commons Attribution Noncommercial License which permits any noncommercial use, distribution, and reproduction in any medium, provided the original author(s) and source are credited.

\section{References}

Berman, M. (1983). All that is solid melts into air: The experience of modernity. New York: Verso. Brzozowski, S. (1906a). Drogi i zadania nowoczesnej filozofii. In Brzozowski, S. (1973). Kultura $i$ zycie. Warszawa: Państwowy Instytut Wydawniczy.

Brzozowski, S. (1906b). Psychologia i zagadnienie wartości. In Brzozowski, S. (1973). Kultura i życie. Warszawa: Państwowy Instytut Wydawniczy. 
Brzozowski, S. (1907a). Przyroda i poznanie. In Brzozowski, S. (1990). Idee. Wstęp do filozofii dojrzatości dziejowej. Kraków: Wydawnictwo Literackie.

Brzozowski, S. (1907b). Filozofia Fryderyka Nietzschego. In Brzozowski, S. (1973). Kultura i życie. Warszawa: Państwowy Instytut Wydawniczy.

Brzozowski, S. (1907c). Aleksander Hercen. In Brzozowski, S. (2007). Gtosy wśód nocy. Studia nad przesileniem romantycznym kultury europejskiej. Warszawa: Wydawnictwo Krytyki Politycznej.

Brzozowski, S. (1907d) Ludzkoś́́ i naród. In Brzozowski, S. (1973). Kultura $i$ życie. Warszawa: Państwowy Instytut Wydawniczy.

Brzozowski, S. (1907e). Wspótczesna krytyka literacka w Polsce. Stanisławów: A. Staudacher i Sp.

Brzozowski, S. (1907f). Religia i spoteczeństwo. In Brzozowski, S. (1973). Kultura i życie. Warszawa: Państwowy Instytut Wydawniczy.

Brzozowski, S. (1909a). Kryzys w literaturze rosyjskiej. In Brzozowski, S. (2007). Gtosy wśród nocy. Studia nad przesileniem romantycznym kultury europejskiej. Warszawa: Wydawnictwo Krytyki Politycznej.

Brzozowski, S. (1909b). O Maurycym Mochnackim. In Brzozowski, S. (2007). Gtosy wśród nocy. Studia nad przesileniem romantycznym kultury europejskiej. Warszawa: Wydawnictwo Krytyki Politycznej.

Brzozowski, S. (1910a). Legenda Młodej Polski. Lwów: Księgarnia Polska Bernarda Połonieckiego.

Brzozowski, S. (1910b). Kilka uwag o stanie ogólnym literatury europejskiej II. In Brzozowski, S. (2007). Gtosy wśród nocy. Studia nad przesileniem romantycznym kultury europejskiej. Warszawa: Wydawnictwo Krytyki Politycznej.

Brzozowski, S. (1910c). Etapy sentymentalizmu. In Brzozowski, S. (1990). Idee. Wstep do filozofii dojrzałości dziejowej. Kraków: Wydawnictwo Literackie.

Brzozowski, S. (1910d). Złudzenia racjonalizmu. In Brzozowski, S. (1990). Idee. Wstęp do filozofii dojrzałości dziejowej. Kraków: Wydawnictwo Literackie.

Brzozowski, S. (1910e). Anty-Engels. In Brzozowski, S. (1990). Idee. Wstęp do filozofii dojrzatości dziejowej. Kraków: Wydawnictwo Literackie.

Brzozowski, S. (1973). Kultura i życie. Warszawa: Państwowy Instytut Wydawniczy.

Brzozowski, S. (1990). Idee. Wstęp do filozofii dojrzałości dziejowej. Kraków: Wydawnictwo Literackie.

Brzozowski, S. (2007). Głosy wśród nocy. Studia nad przesileniem romantycznym kultury europejskiej. Warszawa: Wydawnictwo Krytyki Politycznej.

Walicki, A. (1977). Stanistaw Brzozowski-drogi mysli. Warszawa: Państwowe Wydawnictwo Naukowe. 